\title{
Use of financial instruments to increase the capitalization of agro-industrial complexes
}

\author{
Roman V. Chikulaev* \\ Perm State Agro-Technological University, 614990 Perm, Russia
}

\begin{abstract}
The main characteristics of agricultural production in Russia and around the world are: capital intensity, dependence on natural factors, seasonality and relative instability of markets. These factors lead to increased needs of agro-industrial enterprises and their associations in sufficient sources of financing their own activities. Financial sources should not only be sufficient to ensure the main activity but also to assume some safety margin to overcome the decline in financial stability in cases of low yields, seasonal fluctuations in supply and demand, a sharp deterioration in weather conditions. At the same time, producers of agricultural products, goods and services have low investment attractiveness. This is caused by long payback times, technological complexity, high risks of such activities. As a rule, agricultural producers do not have sufficient financial resources to develop production, and at the same time face difficulties in attracting long-term investment from external sources. In such circumstances, financial instruments can become an important and effective way to ensure financing and increase the capitalization of agro-industrial complexes. Therefore, an important task of the economy and the organization of agricultural production can be recognized as the development of effective mechanisms to attract investment and the formation of their own working capital funds of agricultural producers by issuing and organizing the turn of corresponding financial instruments, including securities.
\end{abstract}

\section{Introduction}

Agriculture is the most important and largest branch of the national economy both in Russia and in other countries of the world, for example, the United States, China, Spain, Italy, etc. The main indicators of agricultural production in Russia over the past few years have generally tended to increase. So the total volume of agricultural production amounted for 2015 - 5164.9 billion rubles (84.7 billion US dollars), for 2016 - 5505.7 billion rubles ( 82.1 billion US dollars), for 2017 - 5654 billion rubles (96.9 billion US dollars). General indices of agricultural production for all categories of producers amounted to 102.6 in 2015 , 104.8 in 2016 and 102.4 in 2017. The yield of grain and leguminous crops in all agricultural producers of all categories in centner per hectare of harvested area amounted for 2015 - 23.7, for 2016 - 26.2, for 2017 29.2. [1]. At the same time, exports of food products and agricultural raw materials in 2016 increased by $5.2 \%$ from 16202 million US dollars compared to 2015 up to 17044 million US dollars, and imports fell $6.3 \%$ from 26584 million US dollars up to 24902 million US dollars. At the same time, the total trade turnover decreased by $2 \%$ from 42805 million US dollars to 41946 million US dollars, the trade balance remains negative [2].

In Russia, there are more positive trends in agricultural development than negative ones. However, negative phenomena also occur. This proves the need to increase attention to financing instruments along with technological and organizational modernization of agroproduction.

Investments in the sphere of agriculture, hunting and forestry by comparison with the sphere of financial activity for the corresponding periods for analytical purposes are presented on the basis of data of the Federal State Statistics Board of Russia, in Tables 1, 2. At the same time, the average annual data on the exchange rate were used to calculate the equivalent in US dollars [3].

Table 1. Investments in fixed assets and fixed capital in agriculture

\begin{tabular}{|l|c|c|c|c|c|c|}
\hline \multicolumn{1}{|c|}{$\begin{array}{c}\text { Industry sector and } \\
\text { index }\end{array}$} & 2005 & 2010 & 2011 & 2012 & 2013 & 2014 \\
\hline $\begin{array}{l}\text { Agriculture, hunting and } \\
\text { forestry }\end{array}$ & & & & & & \\
\hline 1. Fixed assets: & & & & & & \\
\hline billion rubles & 1440 & 2860 & 3127 & 3335 & 3672 & 3886 \\
\hline billion US dollars & 50.9 & 94.1 & 106.4 & 107.2 & 115.5 & 101.2 \\
\hline $\begin{array}{l}\text { \% of the total national } \\
\text { economy }\end{array}$ & 3.5 & 3.1. & 2.9 & 2.7 & 2.8 & 2.7 \\
\hline $\begin{array}{l}\text { Volume index for the } \\
\text { year }\end{array}$ & 97.9 & 101.2 & 101.8 & 101.6 & 102.2 & 101.9 \\
\hline $\begin{array}{l}\text { 2. Investments in fixed } \\
\text { assets: }\end{array}$ & & & & & & \\
\hline billion rubles & 142 & 304 & 447 & 476 & 517 & 503 \\
\hline billion US dollars & 5.0 & 10.0 & 15.2 & 15.3 & 16.2 & 13.1 \\
\hline $\begin{array}{l}\text { \% of the total national } \\
\text { economy }\end{array}$ & 3.9 & 3.3 & 4.1 & 3.8 & 3.8 & 3.7 \\
\hline \begin{tabular}{l} 
olume index for year \\
\hline
\end{tabular} & 109.5 & 89.1 & 134.8 & 101 & 103.9 & 93 \\
\hline
\end{tabular}

* Corresponding author: profur1@ngs.ru 
Table 2. Investments in fixed assets and fixed capital in Financial activity

\begin{tabular}{|l|c|c|c|c|c|c|}
\hline $\begin{array}{c}\text { Industry sector and } \\
\text { index }\end{array}$ & 2005 & 2010 & 2011 & 2012 & 2013 & 2014 \\
\hline \multicolumn{7}{|c|}{ Financial activity } \\
\hline \multicolumn{7}{|c|}{1. Fixed assets: } \\
\hline billion rubles & 494 & 2154 & 2071 & 2519 & 2603 & 2674 \\
\hline billion US dollars & 17.4 & 70.9 & 70.4 & 81 & 81.9 & 69.6 \\
\hline $\begin{array}{l}\text { \% of the total national } \\
\text { economy }\end{array}$ & 1.2 & 2.3 & 1.9 & 2.1 & 1.9 & 1.8 \\
\hline $\begin{array}{l}\text { Volume index for the } \\
\text { year }\end{array}$ & 104.5 & 105.8 & 107.9 & 110.4 & 108.7 & 105.0 \\
\hline \multicolumn{7}{|c|}{ 2. Investments in fixed assets: } \\
\hline billion rubles & 49.4 & 119.7 & 159.2 & 204.2 & 186.7 & 154.5 \\
\hline billion US dollars & 1.8 & 3.9 & 5.4 & 6.6 & 5.9 & 4.0 \\
\hline $\begin{array}{l}\text { \% of the total national } \\
\text { economy }\end{array}$ & 1.4 & 1.3 & 1.4 & 1.6 & 1.4 & 1.1 \\
\hline $\begin{array}{l}\text { Volume index for the } \\
\text { year }\end{array}$ & 110.8 & 112.9 & 125.1 & 120.6 & 87.6 & 80.2 \\
\hline
\end{tabular}

Thus, there are generally comparable dynamic indicators of investment development both in agricultural production and in the financial market for the period preceding the crisis in the financial market in 2014. The investments in fixed assets have a stable upward trend. The investments in fixed assets are more subject to fluctuations, but in agriculture they are more stable, have a lower rate of decline, which began to be observed only in 2014. The structure of investments in both fixed assets and fixed capital is changeable, but depends on many macroeconomic factors, and therefore its dynamics alone cannot be assessed positively or negatively. At the same time, there is some structural balance and matching the pace of structural changes in agriculture and in the financial sector.

There are reasons to assume that the volume and structure of the Russian financial market correspond to the investment needs of the agricultural industry. It can serve as a mechanism for ensuring the inflow of financial investments, transformed into real assets of agricultural enterprises. The development of financial and instrumental methods of investment in the agricultural industry should be considered as means of capitalization of both individual agricultural producers and agricultural complexes in the regions and the country as a whole.

The growth of capitalization on the one hand provides an increase in the investment value of agroindustrial units (including the exchange rate growth of their securities). On the other hand has a positive effect on the growth of physical volumes of fixed assets and current assets of each subject of the agro-industrial complex.

\section{Methods and materials}

In this article the following scientific methods are used: method of analysis and synthesis, method of scientific abstraction, formal logical method, methods of dialectical logic, methods of induction and deduction, methods of comparison and analogy, historical and analytical method, empirical method of research. Special methods of economic science: positive and normative analysis, functional analysis, equilibrium approach, verification method, economic modeling, statistical observation. Private methods of legal science: comparative legal method, the method of legal modeling. The basis for the study is presented by the statistical materials, the latest scientific developments on the main problem, fundamental classical scientific works on the theory of the studied issues, the content of laws and other regulations. The article reflects the results of the author's processing of accumulated materials, the results of the involved observation of phenomena and processes, the results of the analysis and generalization of facts, econometric calculations carried out by the author.

\section{Results and discussion}

In the Russian Federation, as a social type state, special attention is paid to ensuring food security in order to protect the population from possible adverse factors inherent in agricultural production, as well as to minimize the impact of geopolitical and geo-economical factors such as: sanctions, world markets fluctuations, crop yields that do not grow in the climatic zone of Russia, etc. Institutional and normative basis of the State program of development of agriculture and regulation of agricultural products markets, raw materials and food for 2013-2020, the Federal Law "On agriculture development", the Concept of long-term socio-economic development of the Russian Federation for the period up to 2020. The Food Security Doctrine of the Russian Federation, the Strategy of sustainable development of rural territories of the Russian Federation for the period till 2030 and others Federal and departmental regulation and target programs for the development of the agroindustrial complex and ensuring food security of the country.

At the same time, the basis for application in the business practice of financial instruments are legislative acts of the Russian Federation on financial instruments and securities, including the Civil code of the Russian Federation, Federal Law "On the securities market", the Bank of Russia Instruction "On the types of derivative financial instruments", etc. Radical changes in the system of regulation of the issue and turn of financial instruments have been taking place since 2013, when the regulations on corporations were introduced into key legislative acts, as well as the regulations on securities and derivative financial instruments were significantly modernized. In 2009, in the Russian legislation, in the Federal Law "On the securities market" appeared a complex generic concept of "financial instrument", which included two specific subclasses - securities and derivative financial instruments. Over the ten years of dynamic development of the regulatory framework, the concept of a financial instrument began to acquire more definite outlines and become filled with practical significance.

In terms of securities, a number of new objects appeared, the regime and procedure for the issuance and circulation of many existing securities was clarified, and 
some securities were excluded from the law due to their lack of demand in economic practice. As for derivative financial instruments, by 2015 , in compliance with the provisions of the law, the Bank of Russia has established specific types, defined the General procedure for the use of such instruments in the financial markets. In addition, derivatives become a stable practice of institutional and individual investors become one of the main ways to preserve invested funds from inflation. It gives possibility of extracting investment income exceeding the inflation rate including the guarantee of capital protection from market fluctuations and volatility, preserving the primary value of investments.

In recent years, an effective means of developing the circulation of financial instruments, which previously existed mainly in paper form, has become a computerized processing of information, securing rights and obligations in electronic form. Digitalization of such information has led to a new integrative result. It is not only for facilitating and reducing the costs of transactional activity in the stock market, but also to a significant increase in capitalization, qualitative growth in output and circulation. Moreover, it is possible to expansion of the species diversity of stock instruments.

For the purposes of capitalization, as well as servicing the main activities of agro-industrial companies, the same types of financial instruments can be used for other economic entities. The sectoral nature can cause a number of features. Among the main financial instruments of interest as a means of solving economic problems of agricultural enterprises can be identified below shares, bonds, issuer options, depositary receipts, derivatives, holding instruments.

\subsection{Shares}

The legal regime of the share is generally established by the Federal Law "On the securities market" and specified in the Federal law "On joint stock companies". From the agricultural producer point of view the shares are of interest primarily. It is important in cases when a new joint-stock company creating or an existing business corporation could transform into such a form. Given that members of the agro-industrial corporation may be many individuals, including former members or employees of other agricultural structures (collective and state farms, cooperatives).

It is for them joint form the most convenient way of selling their corporate rights to participate in agricultural production, financing the activities of the corporation and the distribution of profits through equity participation. In cases where the number of potential participants in this kind of corporate relations exceeds fifty, the shareholder form becomes the only possible due to the requirements of the law. The form of a public joint-stock company corresponds to the objectives of external attraction of investment share capital to the greatest extent.

The minimum amount of authorized capital of 100000 rubles (about 1500 US dollars) in modern economic conditions cannot become an obstacle to the initial issue of shares. The corporate shareholder form allows ensuring a combination of personal and corporate participation, to establish a balance of interests of the shareholder-owner and shareholder-employee. Additional incentives are also provided to increase productivity through real participation in the management of the corporation and the distribution of profits in the form of dividends. The instrument of preferred shares also retains its importance, including the possibility of issuing different types of shares, each of which can provide a differentiated amount of rights, primarily a guaranteed dividend.

At the same time, the issue of shares involves a number of formalities, including registration of the issue, the report on the issue, the prospectus in cases of volume issues, mainly aimed at attracting a large number of new investors and large investments, disclosure of information. Practice of performance of formal procedures, including administrative fixing of their main stages with registration in Bank of Russia points to long and difficult character of their passing for the agricultural enterprises.

Such procedures may not be quite convenient due to the territorial remoteness of regional agricultural companies from the registration authority, as well as the complicated nature of registration of legally significant documents, which requires the involvement of narrow specialists. As an additional obstacle to the use of the joint-stock form of agricultural business, many entities consider the mandatory transfer of the function of maintaining the register of shareholders to a specialized person-the Registrar on a contractual that is, a fee basis.

It is possible that the establishment of a special legal regime for the shares of agro-industrial corporations should be considered as promising directions of the dynamics of the shareholder legislation. This does not exclude a simplified procedure for issuing shares, including without registration of the issue and the issue report, especially in cases where the issue is not accompanied by the approval of the prospectus. By analogy with some other instruments, the issue of shares of agricultural corporations could be carried out in the notification procedure, with the assignment of the issued securities identification, not registration number.

It is not excluded by the establishment of a special regime for the circulation of such shares, including some limitation of the range of investors. In particular, such shares or their individual types with certain conditions (for example, increased profitability and risk) may be recognized as financial instruments intended for qualified investors, the status of which is currently specifically defined in the Federal Law "On the securities market". Thus the share of agricultural corporation may acquire the value of a single type of securities - a financial instrument that does not rule out a return to the ability to register such shares by joint stock agricultural company, in particular normative order, but without the involvement of the Registrar.

At present time, the Russian service of corporate information disclosure "INTERFAX" contains information about 2941 joint-stock companies related to the agricultural industry [4]. Among them are such large producers - corporations as JSC APK "Belorechenskoe," 
JSC APK "Kosmodemyanskaya", JSC APK "Rus", JSC AP "Michaylovskoye", JSC "AK Gorki-2", JSC AK "Otradnoe", JSC APO "Aurora", JSC "APH", JSC "AgroInvest", JSC "Agrofirma Feniks, JSC "Agrokombinat "Moskovskiy" JSC Agrokompleks Rassvet", JSC "Agroob'edinenie "Kuban", JSC "Agricultural company", JSC "Volga", JSC "KSP "Volna", JSC "Kuban" and etc. Among the largest agricultural producers, the shares of which are freely traded on the Russian stock market, can be called JSC "Cherkizovo Group", JSC "Rusagro", JSC "Razgulay", JSC "Agrofirma Mtsenskaya", JSC "FOS-agro", etc.

Taking into account the fact that in 2017-2018 the total investments in the agricultural sector increased by an average of 10-15\%, agro-industrial joint-stock companies should be recognized as one of the most promising objects that combine investment interest and social significance. Capitalization of such joint-stock companies, primarily by increasing the volume of issue and turnover of their financial instruments (shares, but not only) can be considered as one of the most important organizational and economic tasks.

Financing of the agro-industrial complex is also carried out indirectly, through special financial institutions such as JSC "Rosselkhozbank "and JSC "Rosagroleasing". The main method is also the formation of share capital through financial instrumentshares. Thus according to Rosstat, the additional capitalization of JSC "Rosselkhozbank" in 2015 amounted to 10 billion rubles, or 0.16 billion US dollars, in 2016 - 8 billion rubles or 0.12 billion US dollars. The contribution to the share capital of JSC "Rosagroleasing" was made in 2015 and amounted to 2 billion rubles or 0.03 billion US dollars. JSC "Rosselkhozbank" implements the strategic goals of the state in the agroindustrial complex and occupies a leading position in lending to the agro-industrial complex.

Thus, the share of JSC "Rosselkhozbank" in the total volume of lending to agriculture in 2016 amounted to $66.6 \%$, including short - term lending - $66 \%$, investment lending - $68.3 \%$. Additional capitalization of JSC "Rosselkhozbank" allows consolidating the positive dynamics of lending to the agro-industrial complex in order to accelerate import substitution and development of export potential of domestic producers by simplifying the access of agricultural producers to credit funds [2].

\subsection{Bonds}

The legal regime of the bond is established by the Federal Law "On the Securities Market" quite briefly. According to the law, a bond is a security granting the right of the owner to receive from the issuer a nominal value or other property equivalent, as well as a percentage of the value or other property.

In 2018, the legal regime of the bond changed towards expanding investment opportunities. Bondholders received new rights depending on the peculiarities of the bond issue. Nowadays the bond can be repaid not only at a predetermined time, but also at any other time depending on the circumstances established during its issuance. Bond income traditionally defines percent or discount, but does not disclose the legal significance of these concepts. In such circumstances, these concepts are interpreted on the basis of law enforcement and investment principles.

A percentage is usually considered to be the share of a unit of face value, multiplied by 100 , set at the issue of a security. However, the law allows the determination of percent not only depending on the nominal value. At the same time, in addition to percent, the bondholder may have any other property rights not expressly specified in the law. Such rights are established by the issuer of the bond and are specified in the bond itself (if the bond is documentary) or in the decision on issue (in case of nondocumentary form).

The concept of discount refers to the sphere of investment economy and the law does not disclose. Discount can be defined as the difference between the price of sale (placement) of the security to the investor and the price of its redemption (repayment) by the issuer. It is necessary to take into account that the economic importance of discount is broader and may include a discount or premium to market prices.

The characteristics of the bond indicate the expanded possibilities of using such a tool by economic entities in need of investment, including agricultural producers. Thus, a bond loan can become an effective economic alternative to other debt sources of financing. Especially if the terms of the bond issue provide for a balance of interests of investors and the issuer allow attracting financing at a reasonable rate of payment for the use of funds. Including payment of the income on the bond not in money, and for example in kind, including the made production, payment (issue) of the property income periodically, according to the factor of seasonality, and also taking into account such circumstance-the factor as productivity can be provided. In the literature there is quite extensive, but disparate information about the issuance of bonds by agricultural producers, including in the Russian regions.

The average yield on such instruments was 5-10\%. Obviously, many entities have tried to use the bond instrument of investment financing, but a stable practice of its widespread use by agricultural companies has yet to develop. Currently, the largest Issuer of both corporate and exchange-traded bonds is JSC "Rosselkhozbank". According to the Moscow Exchange admitted to the open circulation of bonds of JSC "Avangard-Agro", LLC "Agro", LLC "Agronova-L", LLC "Agrofirma "Rubezh", LLC "Ob'edinenie Agroelita", LLC "FES-agro" [5]. As can be seen, a significant investment advantage of bonds is the possibility of their issuance by non joint-stock corporations (limited liability companies), which is actively used by agro-industrial companies.

It is also characteristic that the volume of stock trading on the Moscow Exchange in the coming years (2016-2017) is unchanged and amounts to about 9 trillion rubles (about 140 billion US dollars). At the same time, the trade turnover of bonds increased by $25 \%$ in 2017 and amounted to 16.6 trillion rubles (about 250 billion US dollars). 


\subsection{Option of the Issuer}

It is one of the few securities that have been introduced into Russian legislation to expand investment instruments, but have not yet found wide application for this purpose. Modern regulation of the financial instruments turnover in General focuses on establishing a set of rules, regulations, description of the legal regime of each instrument with varying degrees of detail, but does not consider as the main goal to ensure investment needs, does not pay enough attention to the construction of financial instruments as objects that mediate financing and capitalization. Theoretically, the Issuer's option by its construction is a classic derivative security that is, based on other primary securities, namely shares of a corporate Issuer, securing the right of the option holder to buy a predetermined number of shares of the same Issuer and become its shareholder, upon the occurrence of certain events. At the same time, the Russian legislation did not accept the idea of division of securities into primary and derivative, but focused on the development of other derivatives - derivative financial instruments based on other basic assets and not related to securities at all. Nevertheless, when implementing the idea of allocating an independent group of securities of agro-industrial corporations, the Issuer's option can become a means of increasing investment activity and a method of additional financing, including providing the right to receive additional shares of the corporation upon the occurrence of special conditions specific to the sphere of agriculture. In the practice of the Russian financial market, the issue of options took place only sporadically, by large companies in the non-agricultural sector, such as JSC "LUKOIL", JSC "VimpelCom", JSC "RusHydro", in order to solve narrow-profile problems of personnel management.

\subsection{Depositary receipts}

Such instruments can also be referred to derivative securities, i.e. issued only in the presence of other securities having such financial and cost indicators, without which it is impossible to form the structure of a derivative paper. From the standpoint of investment accessibility in the conditions of modern financial markets, we can talk about Russian Depositary receipts (RDR), directly provided for by the Federal Law "On the securities market", but also about international receipts American (ADR) and European (Global - GDR). As in the case of the Issuer's option, Russian Depositary Receipts have not been singled out as derivative securities and can be characterized as instruments of a special kind issued in accordance with the established procedure by an Issuer authorized to secure the right of the RDR holder to a certain number of shares, bonds or other securities of a foreign Issuer, as well as the right to claim such securities and to assist in the exercise of the rights enshrined in them. Thus, two types of financial instruments - national Russian (RDR) and international (ADR, GDR) - were actually involved in the market turnover. At the same time, foreign receipts may be issued by daughter companies of Russian corporations registered abroad and admitted to listing on foreign exchanges.

It should be noted that large Russian agricultural producers use such a tool. Including on the Moscow Exchange and the London Stock Exchange quoted instruments such as GDR of JSC "Rusagro" (Ticker AGRO). Cherkizovo's GDR are also traded on the London Stock Exchange. Thus, there is a somewhat unusual situation in which Russian agricultural companies introduce their financial instruments intended for domestic investors on the Russian stock market, but the instruments themselves are foreign and are offered to the investor indirectly through a special type of Russian securities (RDR), the underlying asset of which are foreign securities of Russian residents. It can be assumed that both RDRs and GDRs and ADRs are a promising means of developing the investment capitalization of agricultural corporations, but available only to large issuing companies and a limited number of investors, also predominantly institutional or qualified.

\subsection{Derivative financial instruments}

The rules on derivative financial instruments that are not securities, but together with securities that make up the legal structure of a single object (financial instrument), were introduced into Russian legislation in 2009 and played a revolutionary role. From the standpoint of the development of investment activity and the growth of financial markets, this role can be assessed positively. At the same time, the practical application of derivatives in modern conditions is most observed in the field of institutional financial investments and is used for hedging risks, as well as the basis for the construction of complex financial products that combine a whole set of investment opportunities. At the same time, the very nature of the derivative financial instrument, based on the risk and probabilistic indicators of the investment efficiency of the underlying financial asset, corresponds to the needs of agricultural production.

Thus a general definition of a derivative financial instrument, the Federal Law "On the securities market" includes a Treaty, which may in particular provide for the obligation of the parties periodically or in a lump sum to pay monetary amounts depending on changes in the price of goods, securities, currency exchange rates, interest rates, inflation, prices of other derivative financial instruments, as well as the values of the statistical indicators of the physical, biological, and chemical indicators of the state of the environment, or from changes in values, calculated on the basis of the above indicators. Indicators that can serve as the basis for the calculation, as well as requirements for basic assets, are specified in the regulations of the Bank of Russia.

In particular, The Bank of Russia No 3565-U Instruction specifies the types of derivative financial instruments, which are understood as the types of relevant contracts of a special kind: option, futures, forward, swap contracts, as well as mixed contracts and specially unnamed contracts. Thus, the list of types of 
derivative instruments today is open. It is the mixed and complex contracts that do not have a special name that are most common in the Russian market of financial instruments in modern conditions. Based on the essence of the derivative financial instrument, there are all grounds to consider it as one of the most promising means of attracting investments in agro-industrial complexes, while indicators of natural factors, productivity, environmental conditions; seasonal fluctuations in prices for agricultural products can act as a basic asset.

\subsection{Financial instruments of holdings}

One of the urgent problems of the organization and legal regulation of effective economic structures in Russia and in other countries can be considered a set of issues of holdings. The problems of holdings are considered by foreign authors in different aspects: the impact on minority shareholders [6], the position of professional associations [7] and regulatory authorities [8] and the use of holdings for restructuring [9], the problems of legislation on mutual holdings [10].

At the same time, the study of the essence of holding structures remains relevant, taking into account the mutual influence of different legal and economic systems, the development of cross-border turnover of financial instruments, increased requirements for transparency and protection of competition, the rules of international financial organizations. In some countries of the world there are special laws on holdings. It is the United States (Public Utility Holding Company Act, Bank Holdings Act), Scotland (Land Holdings Disclosure Act), UK (Agricultural Holdings Act), India (Agricultural Holdings Act), etc. Russia and some other countries have not yet adopted special laws on holdings, and therefore the concept of holding is purely economic, which further enhances its importance.

Even from a short list of the above laws, it can be seen that in some countries holding laws are adopted specifically for agro-industrial companies and large owners of agricultural land. In countries where the holding is not enshrined in law, including Russia requires the settlement of relations, which in essence are somehow holding. Special regulation of agricultural holdings would also be rational.

As it was studied above on the example of other types of financial instruments, usually such instruments (shares, bonds, Issuer's options, etc.) are issued by a single economic entity, a company that is a corporation in form. Thus, financial instruments can be recognized as corporate as they are inextricably linked with the issuing company. The essence of the Russian corporate financial instrument consists in fixing the obligations only of the issuing corporation itself, which causes an indissoluble link between the instrument and the corporation.

However, sometimes it is necessary to break this connection due to objective economic needs, to ensure more efficient forms of management, including holdings. Since the law does not define the legal status of any agro-industrial holding or holding in general, it is not possible to fix the obligations of several interconnected (members of the holding) companies in a single financial instrument. At the same time, especially in the field of agriculture, it would be correct to provide for the issuance of such holding financial instruments that provide mutual financial support to the holding companies and at the same time - increase the liquidity of the financial instrument of the holding. Such an instrument, which can be conditionally called a "holding share", will have a much higher attractiveness for investors due to its provision with assets of not one, but all or several companies belonging to the holding.

The formation of concepts and special regimes for holdings and other business groups, as well as for holding (consolidated) financial instruments, including securities, can be recognized as a promising direction of the reform of legislation and micromanagement. Such instruments should secure the rights of their owners in relation not to one particular organization, but to the entire holding company as a single issuer. For example, the shareholders of the holding should be entitled to dividends and participation in management in relation to all companies belonging to the holding.

The bonds of the holding should reflect the obligation to pay income and par value after repayment by all companies of the holding. Such a scheme will require modifying some traditional views, but its practical implementation will significantly expand business financing opportunities, create additional guarantees for investors, and seriously capitalize companies in certain industries, first of all in the agroindustrial complex.

\section{Conclusion}

In their fundamental work "Economics" K. McConnell and S. Brew identified the main problems of agriculture: annual fluctuations in product prices, inelastic demand, fluctuations in production volumes, the shift in demand, the overall reduction of the agricultural industry [11]. It is necessary to constantly search for sources of financing, co-financing, additional financing, and ultimately capitalization of the agro-industrial complex.

The studied questions of the economic essence of investment financing of agricultural complexes show that one of the most effective methods of increasing capitalization can be the widespread use of financial instruments. Russian legislation has adopted and successfully adapted international experience, including constantly expanding the range of designs of financial instruments known to the legislation of developed foreign countries.

The increased social importance of food security, the adoption of special laws and other regulations aimed at ensuring the sustainability of the Russian agro-industrial complex cause a constant search for new funding opportunities. Despite significant budgetary support, as well as the establishment of special investment structures, such as Rosselkhozbank and Rosagroleasing, not reduced the value of own sources of financing and 
investment for capitalization of private agricultural producers.

Such Russian financial instruments as shares of jointstock companies of the agricultural sector, bonds of agricultural corporations of both joint-stock and nonstock forms can successfully serve these purposes. The development of a special legal regime for shares and bonds of agricultural producers, including the establishment of simplified conditions for their issuance and registration, other benefits and preferences for investors who contribute to the financing of agricultural production is seen as a promising direction of improving the legislation.

A special and developing instrument is Russian Depositary Receipts for securities of foreign subsidiaries of Russian agricultural corporations. In order to be more actively involved in the financial and market turnover, it is necessary to modify the procedure and conditions for issuing options of the Issuer, which is a joint-stock company in the sphere of agriculture. It is possible that a qualitative revision of approaches to the classification of securities and financial instruments in the Russian legislation and economic practice will be required [12].

Special attention should be paid to the regulation of the issue and circulation of derivative financial instruments, the construction of which is currently provided for by law only as a framework. It is possible that the consolidation of the legal regime of all types of derivative financial instruments should be the responsibility of the Federal legislator, and the competence of the Bank of Russia should remain the most important issues of issue and circulation of financial instruments. Derivatives are still an undervalued means of investment financing of agroindustrial complexes.

A return to the idea of fixing classical derivative securities - derivatives in the law is not excluded. The legal structure and economic content of modern Russian derivatives are represented by contractual obligations, the performance of which is dependent on probabilistic and variable circumstances. Since such circumstances are more than typical for agriculture, a deep analysis of the environment for the use of derivative financial instruments in the financial and commodity markets with the participation of agricultural producers, the creation of stimulating conditions for the expansion of the scope of such instruments as means of additional financing is necessary.

As the boundaries of legal understanding and economic essence of financial instruments are constantly expanding, the next step in this direction should be the development of the concept of holding financial instruments. Such a concept should be enshrined in law. One of the main areas of application of such consolidated instruments, produced not by a single corporation, but by a holding business group, can be the sphere of agro-industrial production, taking into account its complex nature, often including in a single technological chain the cultivation of agricultural products, its processing, transportation, wholesale and retail sale to consumers.

\section{References}

1. Statistics: key indicators of agriculture 2015-2017, Retrieved from: https://agrovesti.net/lib/industries/ statistika-osnovnye-pokazateli-selskogokhozyajstva-2015-2017-gg.html

2. On the progress and results of the implementation in 2016 of the State program for the development of agriculture and regulation of markets for agricultural products, raw materials and food for 2013-2020, National report (Moscow, 2017)

3. Agriculture, hunting, forestry in Russia, Statistical compendium (Rosstat, Moscow, 2015)

4. Retrieved from: https://www.e-disclosure.ru/poiskpo-kompaniyam

5. Retrieved from: https://www.moex.com/ru/spot/ issues.aspx

6. G. Zwick, A SBJA change to IRD items for decedents holding $S$ stock, Tax adviser, 28(8), 493 (1997)

7. D. West, Alliance hits Vt. Mutual holding co. Plan. National Underwriter, Property \& Casualty Risk \& Benefits, 101(50), 10 (1997)

8. C. Saucer, A holdout from the mutual holding company bandwagon, Best's review, Propertycasualty insurance edition, 12, 51 (1998)

9. A. Dye, C. Kempler, Making the case for mutual holding companies, National underwriter, Life \& health financial services, 100(36), 36 (1996)

10. D. West, Mutual holding co. Act on hold until fall, National underwriter, Life \& health financial services, 101(31), 3 (1997)

11. R. Campbell McConnell, L. Stanley Brue, Macroeconomics: Principles, Problems, and Policies (McGraw-Hill/Irwin, 2014)

12. R.V. Chikulaev, The Securit. Classificat. and Securit. Legal Construct. Iss., Perm University Herald. Juridical Sciences, 2(16), 160 (2012) 